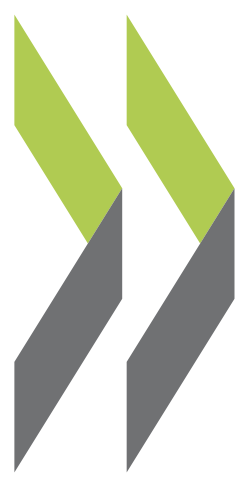

OECD Economics Department Working Papers No. 1005

Debt and Macroeconomic Stability: Debt Volker Ziemann and the Business Cycle 


\section{Unclassified}

ECO/WKP(2012)82

Organisation de Coopération et de Développement Économiques

Organisation for Economic Co-operation and Development

07-Dec-2012

ECONOMICS DEPARTMENT

English - Or. English

DEBT AND MACROECONOMIC STABILITY: DEBT AND THE BUSINESS CYCLE

ECONOMICS DEPARTMENT WORKING PAPERS No. 1005

By Volker Ziemann

All Economics Department Working Papers are available through OECD's Internet website at www.oecd.org/eco/Workingpapers

JT03332420

Complete document available on OLIS in its original format

This document and any map included herein are without prejudice to the status of or sovereignty over any territory, to the delimitation of international frontiers and boundaries and to the name of any territory, city or area. 


\section{ABSTRACT/RÉSUMÉ \\ Debt and macroeconomic stability: Debt and the business cycle}

Using a large panel of OECD countries this paper studies the link between debt and macroeconomic stability by comparing the evolution of balance sheet aggregates and economic output in high- and lowdebt environments. While the relationship between debt and economic growth has been extensively studied in the literature, only little attention has been paid to the impact of debt on volatility and higher moments of output growth distributions. This paper fills in this gap. Debt-fuelled expansions are found to typically last longer but to culminate in a more sizeable downturn. The greater amplitude of business cycles in high-debt environments reflects higher macroeconomic volatility but also higher tail risks and adverse asymmetries in output growth distributions. The induced welfare losses justify policy interventions aiming at preventing excessive build-ups in debt ex-ante.

JEL classification: C23; E32; E44; F34; G01; H63

Keywords: Debt; macroeconomic stability; amplitude of business cycles

$$
* * * * *
$$

\section{Endettement et stabilité macroéconomique : L'endettement et le cycle économique}

S'appuyant sur un vaste ensemble de pays de l'OCDE, ce document étudie le lien entre la dette et la stabilité macroéconomique en comparant l'évolution des agrégats des bilans et de la production économique dans des contextes d'endettement élevé et de faible endettement. Si la relation entre la dette et la croissance économique a fait l'objet de nombreuses études, il n'a guère été prêté attention à l'impact de la dette sur la volatilité et les moments supérieurs des distributions de la croissance de la production. Ce document comble cette lacune. Il constate que les phases d'expansion financée par le recours à l'endettement durent généralement plus longtemps mais se terminent par un ralentissement plus marqué de l'activité. La plus grande amplitude des cycles conjoncturels en situation de fort endettement reflète une plus haute instabilité macroéconomique mais aussi des risques extrêmes plus élevés et des asymétries défavorables dans les distributions de la croissance de la production. Les pertes de bien-être liées à ces phénomènes justifient les interventions des pouvoirs publics visant à éviter une accumulation excessive de dette ex ante.

Classification JEL: C23 ; E32 ; E44 ; F34 ; G01 ; H63

Mots clés : Dette ; stabilité macroéconomique ; amplitude des cycles conjoncturels

\section{(C) OECD (2012)}

You can copy, download or print OECD content for your own use, and you can include excerpts from OECD publications, databases and multimedia products in your own documents, presentations, blogs, websites and teaching materials, provided that suitable acknowledgment of OECD as source and copyright owner is given. All requests for commercial use and translation rights should be submitted to rights@oecd.org. 


\section{TABLE OF CONTENTS}

\section{DEBT AND MACROECONOMIC STABILITY: DEBT AND THE BUSINESS CYCLE ........................5}

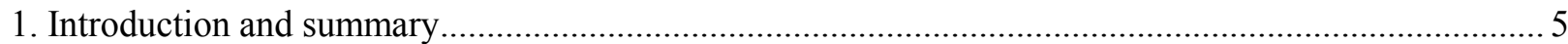

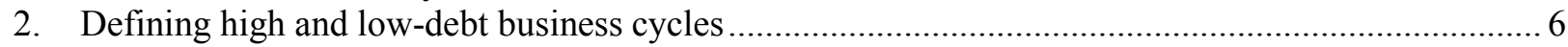

2.1. Balance sheet data across countries - data availability and choices made ...................................... 6

2.2. Debt dynamics and how to account for it ................................................................................ 7

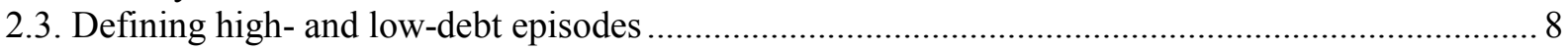

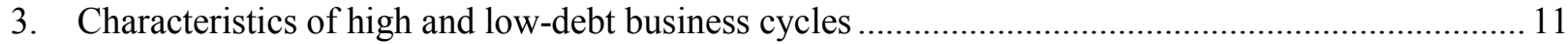

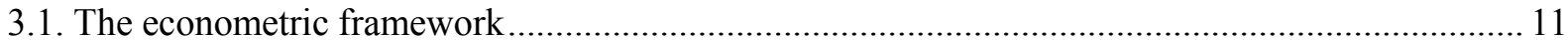

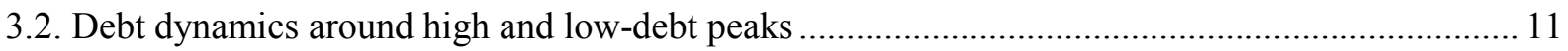

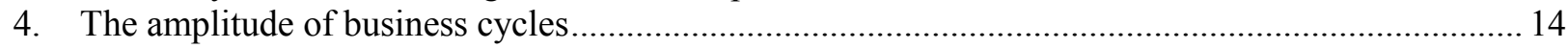

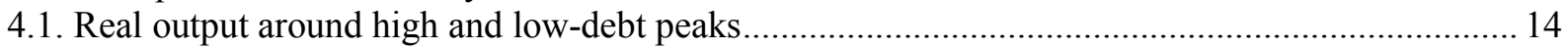

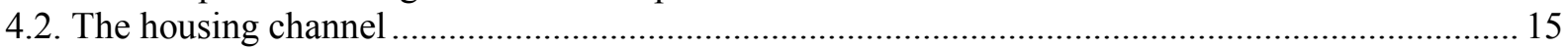

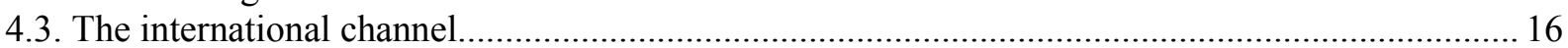

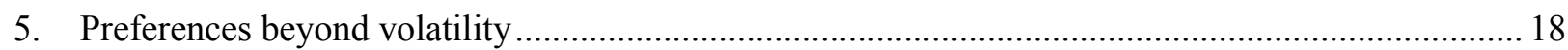

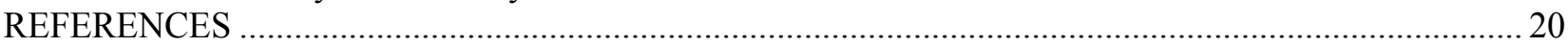

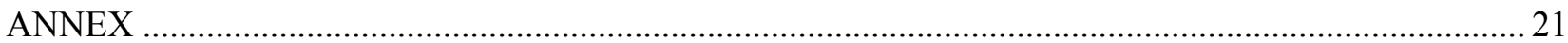

\section{Boxes}

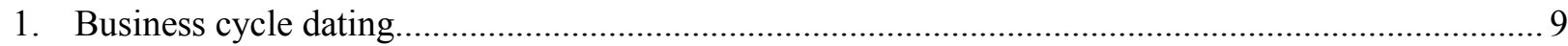

\section{Tables}

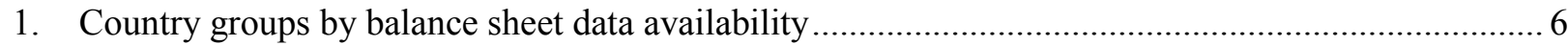

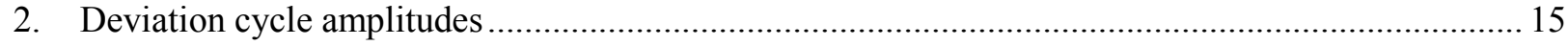

3. Summary statistics for real GDP growth rates by debt regime ..................................................... 19

\section{Figures}

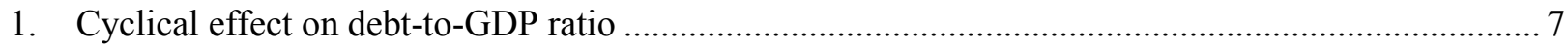

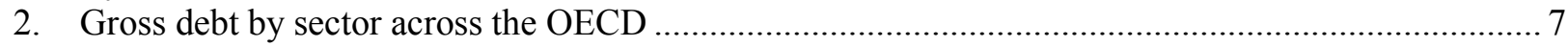

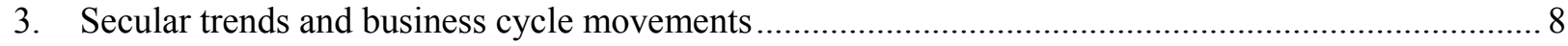

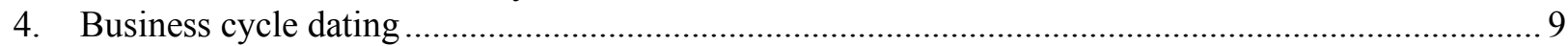

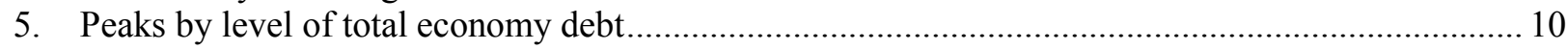

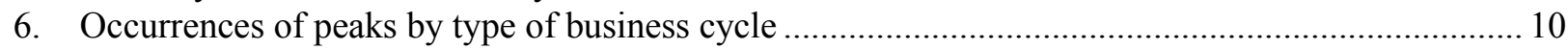

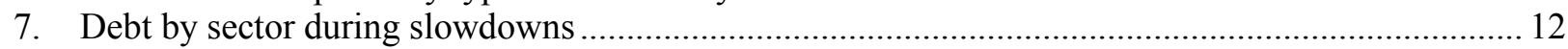

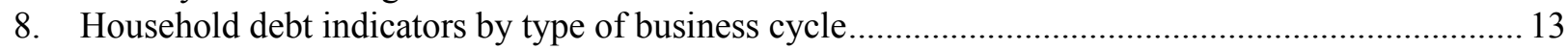

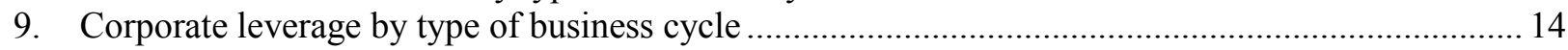

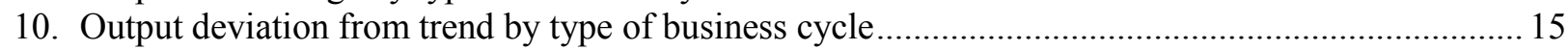

11. Housing investment and capital stock by type of business cycle................................................... 16

12. Exports, imports and the current account balance by type of business cycle ............................... 17

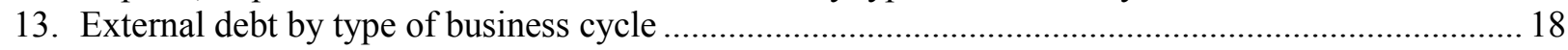

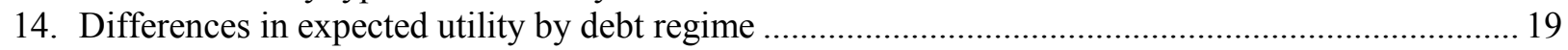

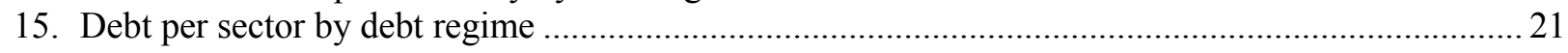

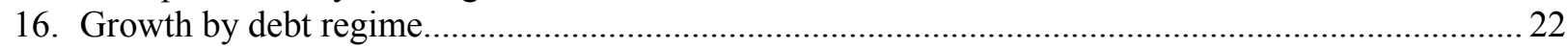




\section{ECO/WKP(2012)82}

The statistical data for Israel are supplied by and under the responsibility of the relevant Israeli authorities. The use of such data by the OECD is without prejudice to the status of the Golan Heights, East Jerusalem and Israeli settlements in the West Bank under the terms of international law. 
ECO/WKP(2012)82

\title{
DEBT AND MACROECONOMIC STABILITY: DEBT AND THE BUSINESS CYCLE
}

\author{
by Volker Ziemann ${ }^{1}$
}

\section{Introduction and summary}

This paper assesses the link between business cycle characteristics and the level of aggregate total economy debt. The paper is related to two strands of the business cycle literature. First, it relates to empirical studies such as Laeven and Valencia (2010) or Schularick and Taylor (2012) who show that the real effects of high debt levels are significantly stronger during banking crises despite more aggressive policy responses. Indeed, banking crises are closely related to debt aggregates as banking crises correspond to periods of financial distress (bank runs, sharp increase in defaults and write-offs, etc.) that ultimately lead to public intervention to shore up bank balance sheets. Instead of comparing banking crises to normal crises this paper compares low to high-debt business cycles.

Second, the paper builds on findings that the recognition of even a low probability for extreme events, or disasters, substantially alters the perception of risk and the related risk premia (e.g. Gourio,2012) and that volatility in general and such risks in particular are associated with welfare losses (see e.g. Barro, 2009 or Epaulard and Pommeret, 2003).

The main findings of the paper are:

- Comparative analyses show that even after accounting for secular trends and country specificities, approximately half of all business cycles associated with high debt occurred in the late 2000s. Gross debt as a share of GDP is roughly five per cent above trend for corporations and households at the peak of high-debt business cycles and decline thereafter, while government debt is $5 \%$ below trend and rises thereafter.

- The empirical results suggest that business cycles amplitudes increase when debt is high. Expansion phases typically last longer albeit at the cost of a more sizeable and prolonged downturn thereafter. These patterns are driven by the private sector while government support, at least temporarily, mitigates the adverse effects of the downturn.

- Private sector debt is substantially more dynamic than disposable income in high-debt periods. On the contrary, financial leverage ratios are broadly in line with long-term trends before high-debt peaks since debt increases are mirrored by increases in assets. However, at the onset of a high-debt slowdown, leverage increases significantly since the value of assets and equity declines more rapidly and more markedly than the value of debt.

1. The author is member of the Economic Department of the OECD. This paper is a revised version of a document prepared for the OECD's project on Debt and Macroeconomic Stability which was presented at a meeting held in October 2012 of Working Party No. 1 of the OECD Economic Policy Committee. The project is summarised in Sutherland et al. (2012) and the other background papers include Merola (2012) and Sutherland and Hoeller (2012). The author is indebted to the participants of the meeting as well as Jorgen Elmeskov, Peter Hoeller, Jean-Luc Schneider and Douglas Sutherland for useful comments and suggestions and to Susan Gascard for excellent editorial support. 
- Current account imbalances also seem to be more pronounced during the expansion phase of high-debt episodes. Trade serves as a shock transmission channel from highly indebted current account deficit countries towards net creditor and current account surplus countries.

- In addition to the increased volatility (amplitude), GDP growth distributions at times of high debt are more negatively skewed and more leptokurtic which adds to expected utility losses induced by increasing volatility especially when risk aversion is high. Accordingly, instead of merely focussing on average growth, policy makers should also take distributional consequences of policy decisions into account, namely volatility and the asymmetry and tail-characteristics of growth distributions.

The remainder of this paper is organised as follows. Section 2 defines high and low-debt episodes and relates them to business cycles. Section 3 investigates how debt aggregates and leverage behave in high and low-debt business cycles. Section 4 establishes stylised facts about swings in economic activity during the two types of business cycles. Finally, section 5 analyses the welfare implications of debt on asymmetry and tail effects of output distributions.

\section{Defining high and low-debt business cycles}

\subsection{Balance sheet data across countries - data availability and choices made}

Regarding the quality of balance sheet data, constructing a coherent debt data set across OECD countries is not straightforward. While most countries report both consolidated and non-consolidated data, 10 countries provide only non-consolidated and two countries only consolidated data. ${ }^{2}$ For the sake of harmonisation, this study is based on non-consolidated annual balance sheet data. ${ }^{3}$ Due to different sample length, the panel is highly unbalanced. The following table summarises information on the availability of annual balance sheet data per country.

Table 1. Country groups by balance sheet data availability

\begin{tabular}{c|c|c|c}
\hline $\begin{array}{c}\text { No data } \\
(4 \text { countries })\end{array}$ & $\begin{array}{c}\text { Between } 5 \text { and } 12 \text { years } \\
(9 \text { countries })\end{array}$ & $\begin{array}{c}\text { Between } 16 \text { and } 18 \text { years } \\
(13 \text { countries })\end{array}$ & \multicolumn{1}{c}{$\begin{array}{c}\text { At least } 20 \text { years } \\
(8 \text { countries })\end{array}$} \\
\hline ISL, MEX, NZL, TUR & CHE, CHL, CZE, DNK, & AUT, BEL, EST, FIN, FRA, & $\begin{array}{l}\text { AUS, CAN, DEU, ESP, } \\
\text { GRC, HUN, ITA, NOR, } \\
\text { IRL, ISR, KOR, LUX, SVN } \\
\text { POL, PRT, SVK, SWE }\end{array}$
\end{tabular}

balance sheet debt data is required in order for a year to count.

Household and government debt refers to gross financial liabilities, while total economy and corporate debt is defined as gross financial liabilities other than equity and financial derivatives. Debt may or may not rise simultaneously with the value of assets or equity and both could influence macroeconomic volatility. In order to distinguish between these situations, various debt indicators are used: debt-to-GDP ratios, household debt-to-disposable income, net financial wealth (households), leverage ratios and debt-to-equity ratios (corporations).

Output developments over business cycles move debt-to-GDP ratios in a counter-cyclical way (Figure 1). For that reason, debt-to-trend-GDP ratios are used in the dating process of high and low-debt

2. Canada, Switzerland, Chile, Czech Republic, United Kingdom, Ireland, Japan, Korea, Turkey and the United States provide only non-consolidated and Australia and Israel provide only consolidated balance sheet data.

3. Except for Australia and Israel where consolidated data is used. 
business cycle peaks. For trend-GDP the OECD's potential output series is used and prolonged backwards, where necessary, using HP-filtered real GDP.

Figure 1. Cyclical effect on debt-to-GDP ratio

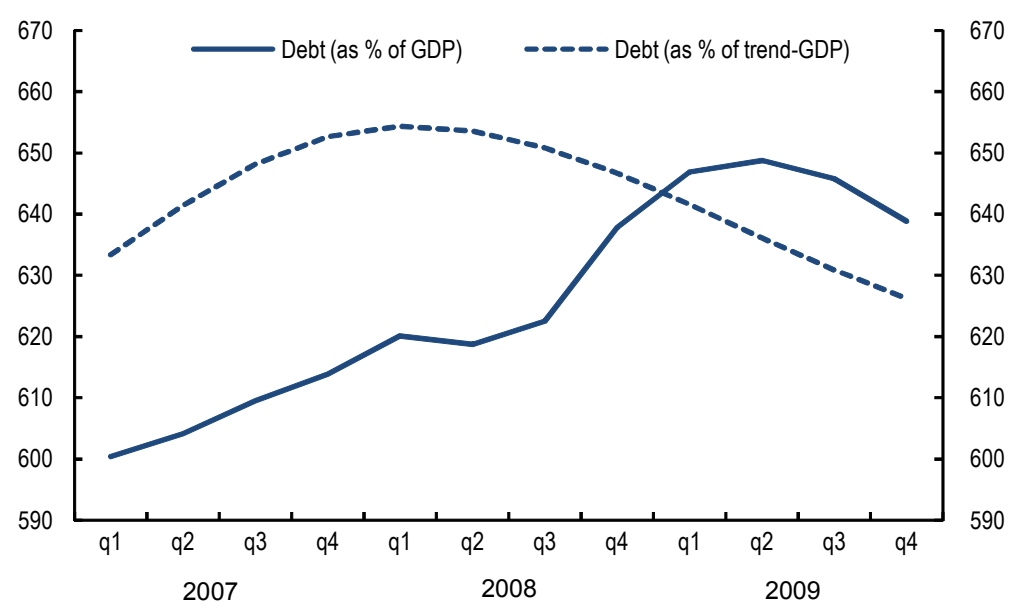

Note: Total economy debt-to-GDP ratio of the United States is shown.

Source: OECD Economic Outlook No. 91 and OECD National Accounts databases.

\subsection{Debt dynamics and how to account for it}

Gross debt as a per cent of GDP has trended upwards over the past 50 years for all institutional sectors (Figure 2). The increase in debt accelerated since the early 1990s and was particularly marked in the financial sector and for households. Their debt-to-GDP ratios roughly doubled over the past 20 years. Gross debt also rose for non-financial corporations and governments, but the rise was less marked.

Figure 2. Gross debt by sector across the OECD

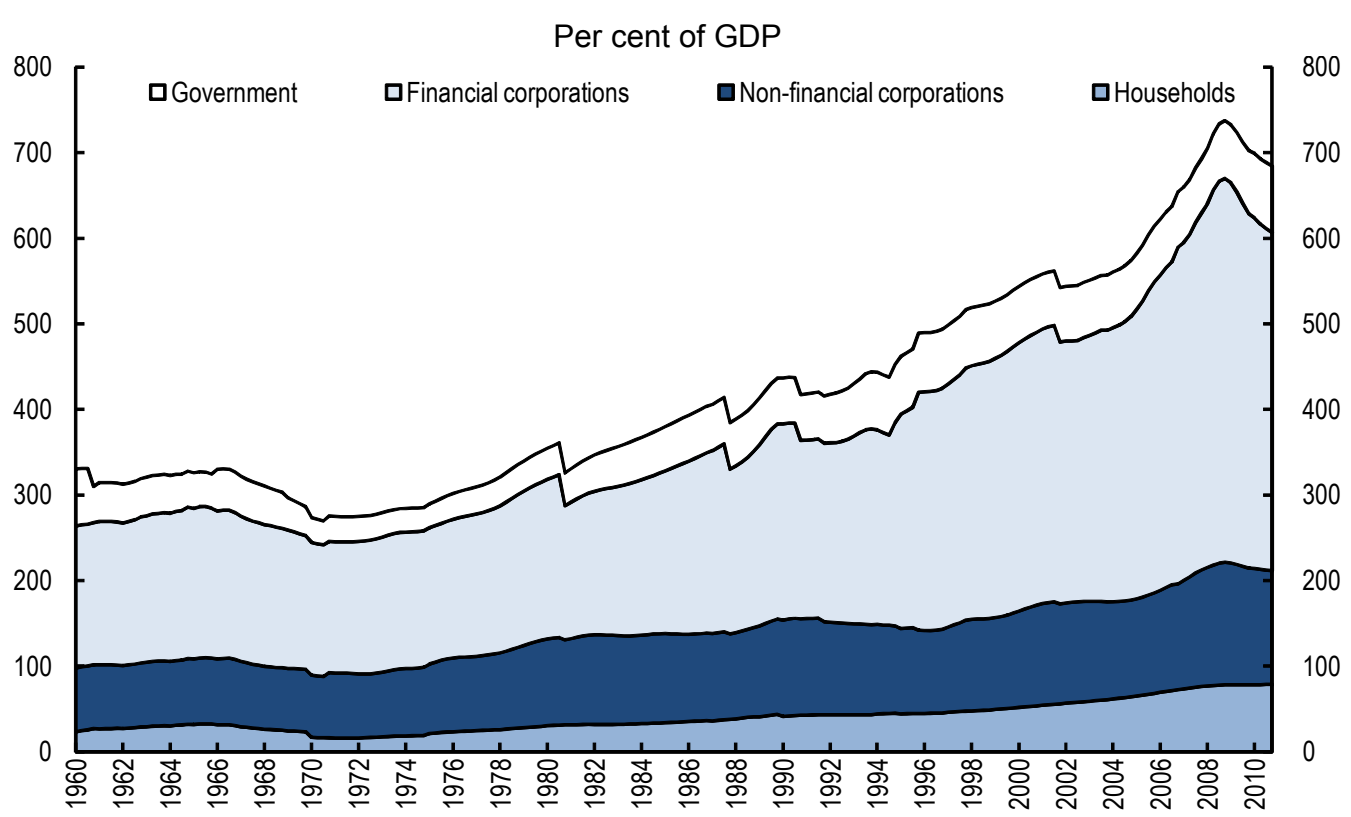

Note: For most European countries, harmonised data for gross debt are only available since 1995. For the others, they start at different time periods before then. Consistent data across sectors prior to 1980 are only available for the United States and Canada. In order to show long series and to eliminate the bias due to an unbalanced panel, panel regressions of debt-to-GDP ratios with country-fixed and time-fixed effects are run and coefficients corresponding to time-fixed effects are shown.

Source: OECD Economic Outlook No. 91 and OECD National Accounts databases. 


\subsection{Defining high- and low-debt episodes}

The upward trend in debt-to-GDP ratios suggests that assuming a constant level of debt over time would not provide a suitable framework for separating high from low-debt episodes. In addition, country specific issues such as the size, openness or state of development of an economy may play a role. Indeed, when separating episodes into high and low-debt business cycle phases, both the size of country and time effects prove to be substantial.

Without country-fixed effects, the occurrence of high-debt business cycles is biased towards countries exhibiting high debt on average while without time-fixed effects, the occurrence of high-debt business cycles is biased towards the end of the sample due to the positive time trend (Figure 1). Indeed, without correcting for time-fixed effects, close to $90 \%$ of the high-debt business cycles occur after 2006. Similarly, without correcting for country-fixed effects, half of the high-debt business cycles are concentrated in just three OECD countries. Accordingly, time and country trends will be accounted for when associating business cycles with high and low-debt periods.

In order to account for secular trends in debt-to-GDP ratios, a pragmatic approach is chosen. Lowand high-debt peaks are assessed by their deviation from a secular trend obtained from a two-sided HP filter. ${ }^{4}$ The crucial parameter here is the smoothing parameter $\lambda$. A value that is too large would result in a linear trend that may not be able to capture non-linear secular movements, while a value that is too small shrinks the amplitude of the de-trended series since it absorbs some movements of the business cycle. The Basel Committee on Banking Supervision (2010) suggested a smoothing parameter of $\lambda=400000$ in order to capture long-term trends. Figure 3 illustrates the methodology.

Figure 3. Secular trends and business cycle movements

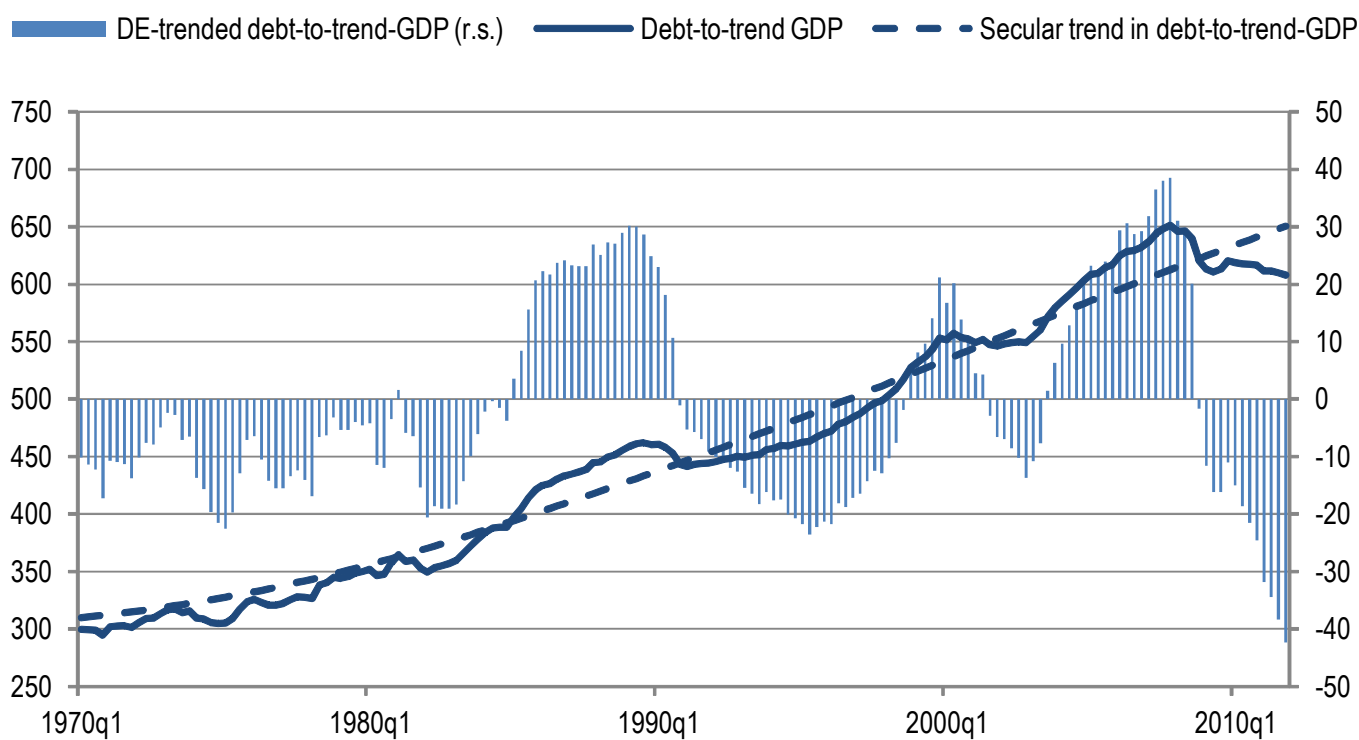

Note: US data are used to illustrate the approach. First, debt is expressed in \% of potential GDP rather than GDP in order to eliminate business cycle noise in the denominator of debt-to-GDP ratios. Second, the secular debt trend is obtained as the HP-filtered debt-to-trend-GDP ratio with the smoothing parameter of $\lambda=400000$.

Source: OECD Economic Outlook No. 91 and OECD National Accounts databases.

4. Alternatively, low and high-debt peaks may be obtained by the deviation from a fundamental or general equilibrium level of debt. Given the multiple sector framework and country specific issues, this is beyond the scope of this paper. 


\section{Box 1. Business cycle dating}

Business cycle characteristics can be measured based on classical business cycles, deviation and growth cycles. Classical business cycles are based on the level of real GDP while deviation or growth cycles are based on the cyclical component of real GDP extracted either through first differencing (growth cycles) or trough filtering techniques that subtract the secular trend (deviation cycle). In order to define turning points, the BBQ algorithm for quarterly data described in Harding and Pasan (2002) is used. As suggested by Canova (2007), and additionally to the required minima of two quarters per phase and five quarters per cycle, a minimum amplitude of $1 \%$ per phase (peak-to-trough or trough-to-peak) is imposed. Figure 4 illustrates the algorithm using US real GDP growth over the past 20 years.

Figure 4. Business cycle dating

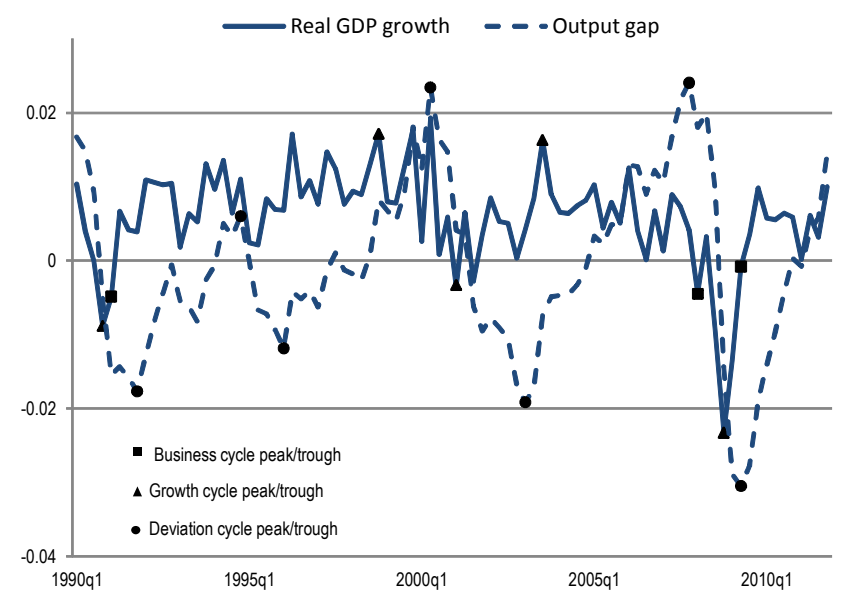

Source: OECD Economic Outlook No. 91 database and author's calculations.

Box 1 illustrates the dating algorithm and the different definitions for business cycles. This paper focuses on deviation cycles rather than classical business cycles or growth cycles. ${ }^{5}$ In total, 100 deviation cycle peaks that occurred before 2010 and for which balance sheet data are available are identified across OECD countries. 70 of these peaks occurred at a time when the debt-to-trend-GDP ratio exceeded its long term trend. The 50 peaks yielding the highest (lowest) de-trended debt-to-GDP ratios are subsequently associated with "high-debt" ("low-debt") business cycles and are shown in Figure $5{ }^{6}$

5. Deviation cycles are better correlated with economically relevant variables (asset returns, unemployment rate, etc.) than classical business cycles since they take structural changes such as productivity or labor market shocks to real GDP into account. Deviation cycles are also more relevant for economic policy tools (e.g. the Taylor rule). The annex shows results for growth and classical cycles as a robustness check.

6. Note that since the number of balance sheet reporting countries increases over time, the number of retained peaks also increases over time. 
Figure 5. Peaks by level of total economy debt

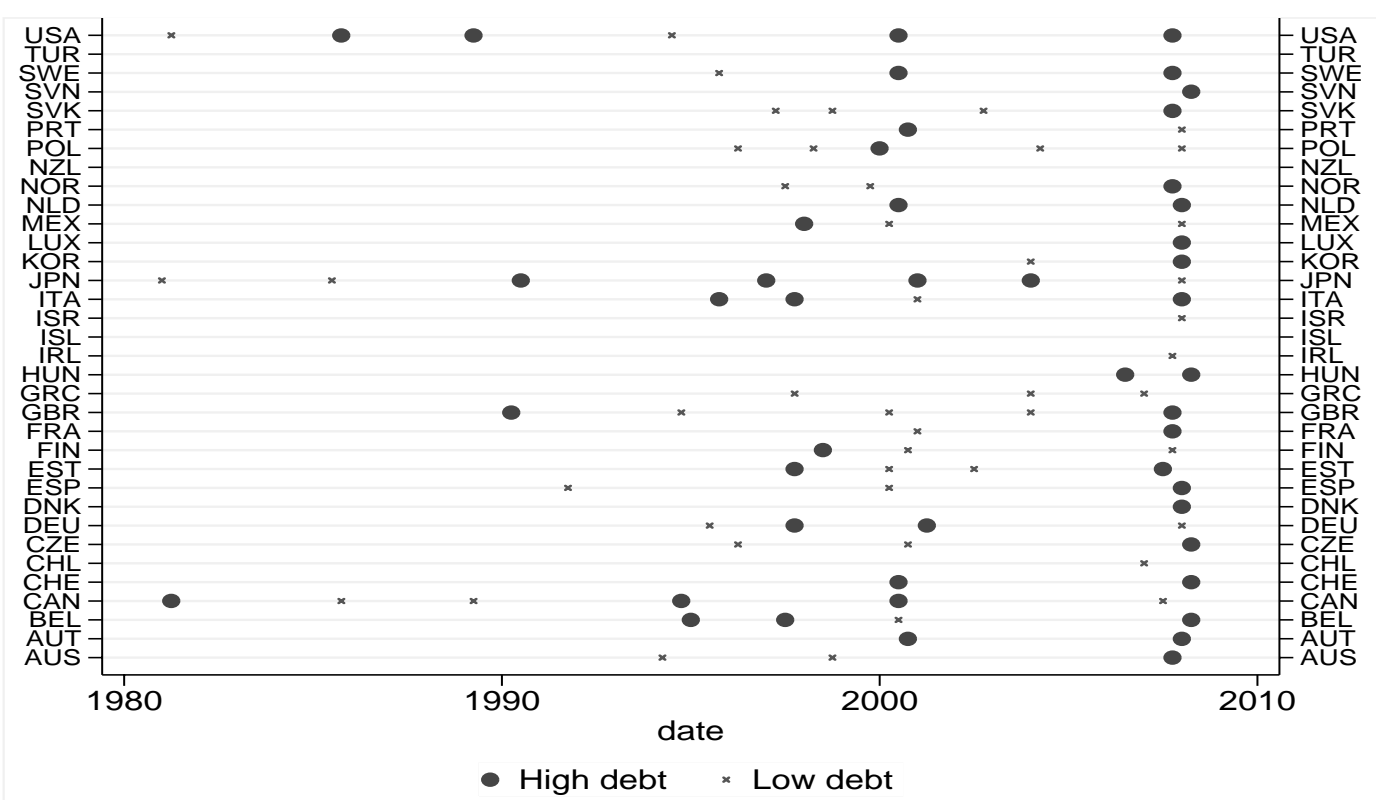

Note: Deviation cycles are split into low and high-debt cycles according to the level of de-trended debt-to-trend-GDP ratios at the output gap peak. Dates of peaks are shown.

Since de-trended debt ratios are used to separate high from low-debt business cycles, the methodology implicitly controls for time and country effects. Given the aforementioned trend in debt-to-GDP ratios, most if not all high-debt business cycle peaks would otherwise occur at the end of the sample. Nonetheless, even when accounting for the upward trend, 23 out of 51 high-debt business cycle peaks occurred prior to the recent financial crisis and only 9 of the 50 low debt peaks occurred after 2006 (Figure 6). The figure further suggests contagion effects of high-debt business cycle slowdowns as multiple occurrences of high-debt peaks seem to increase the number of low-debt business cycle peaks that are otherwise fairly evenly distributed over time.

Figure 6. Occurrences of peaks by type of business cycle

Low debt slowdowns

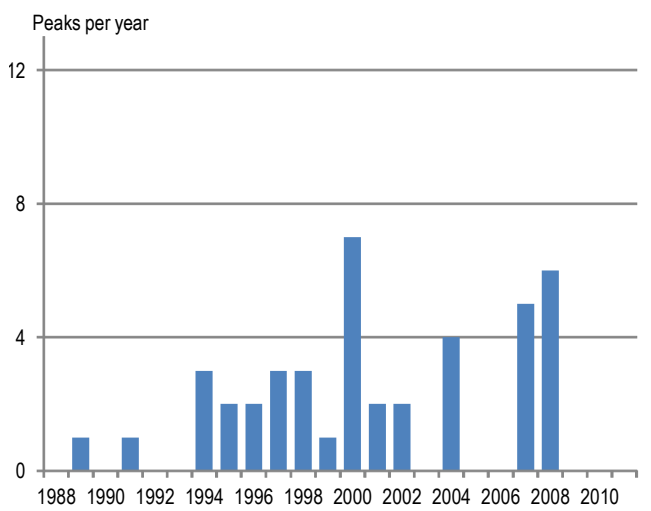

High debt slowdowns

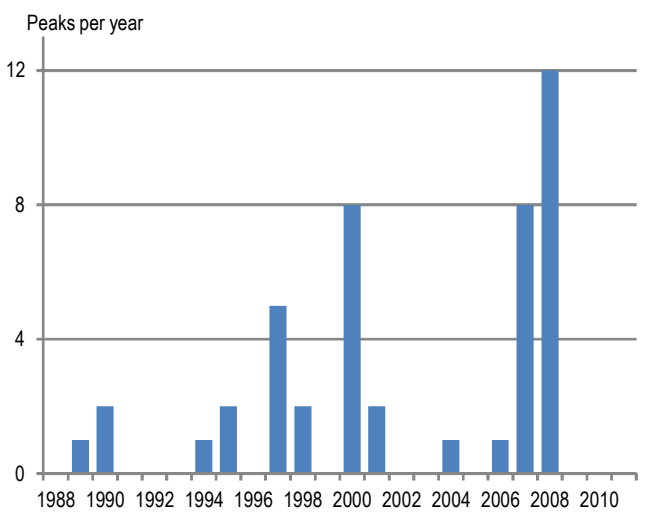

Note: Business cycles are defined as deviation cycles and split into low and high-debt recessions according to de-trended debt-to-trend-GDP ratios at the deviation cycle peak. Occurrences per year across OECD countries are shown. 


\section{Characteristics of high and low-debt business cycles}

\subsection{The econometric framework}

Based on the distinction of high and low-debt deviation cycles, the remainder of the paper assesses the behaviour of monetary and real economy variables during the two types of cycles with a special focus on the peak and the subsequent slowdown. Each variable is regressed on a set of dummy variables defined by its distance from a peak:

$$
x_{i t}=\sum_{j=-4}^{14} \beta_{j} \delta_{i t}^{j}+\epsilon_{i t}
$$

where $x_{i t}$ represents the variable of interest and $\delta_{i t}^{j}$ a dummy variable that takes the value of 1 if in country $i$ a deviation cycle peak occurs at time $t-j$ and 0 otherwise. Dependent variables $x_{i t}$ are detrended using the HP-filter. ${ }^{7}$ Accordingly, the regression coefficients $\beta_{j}$ measure the mean deviation from the long-term trend during the 4 quarters before and the 14 quarters after the peak of deviation cycles. The use of de-trended variables is a parsimonious way of correcting for time- and country-specific trends. Coefficients $\beta_{j}$ in (1) are estimated for low- and for high-debt deviation cycle peaks according to Figure 5.

\subsection{Debt dynamics around high and low-debt peaks}

The results suggest that private debt behaves quite differently than public debt especially in business cycles associated with high total economy debt. Indeed, private debt is generally markedly above trend at the output gap peak, peaking roughly 6 to 8 quarters later and declining towards the trend-level thereafter (Figure 7), while public debt is on average below trend at output gap peaks and rising markedly during the slowdown phase and remaining above trend for an extended period. This is partly due to measures aimed at cushioning the downturn and, in a few countries, to the bail out of financial intermediaries especially in the course of the recent crisis.

7. In order to capture long-term trends, the Basel Committee on Banking Supervision (2010) suggests to use the smoothing parameter $\lambda=400000$. A lower parameter would capture too much of the actual business cycle movement that the specification aims to analyse while greater values for $\lambda$ drives the smoothed variable towards a line which would in turn not allow to de-trend non-linear trends. 
Figure 7. Debt by sector during slowdowns
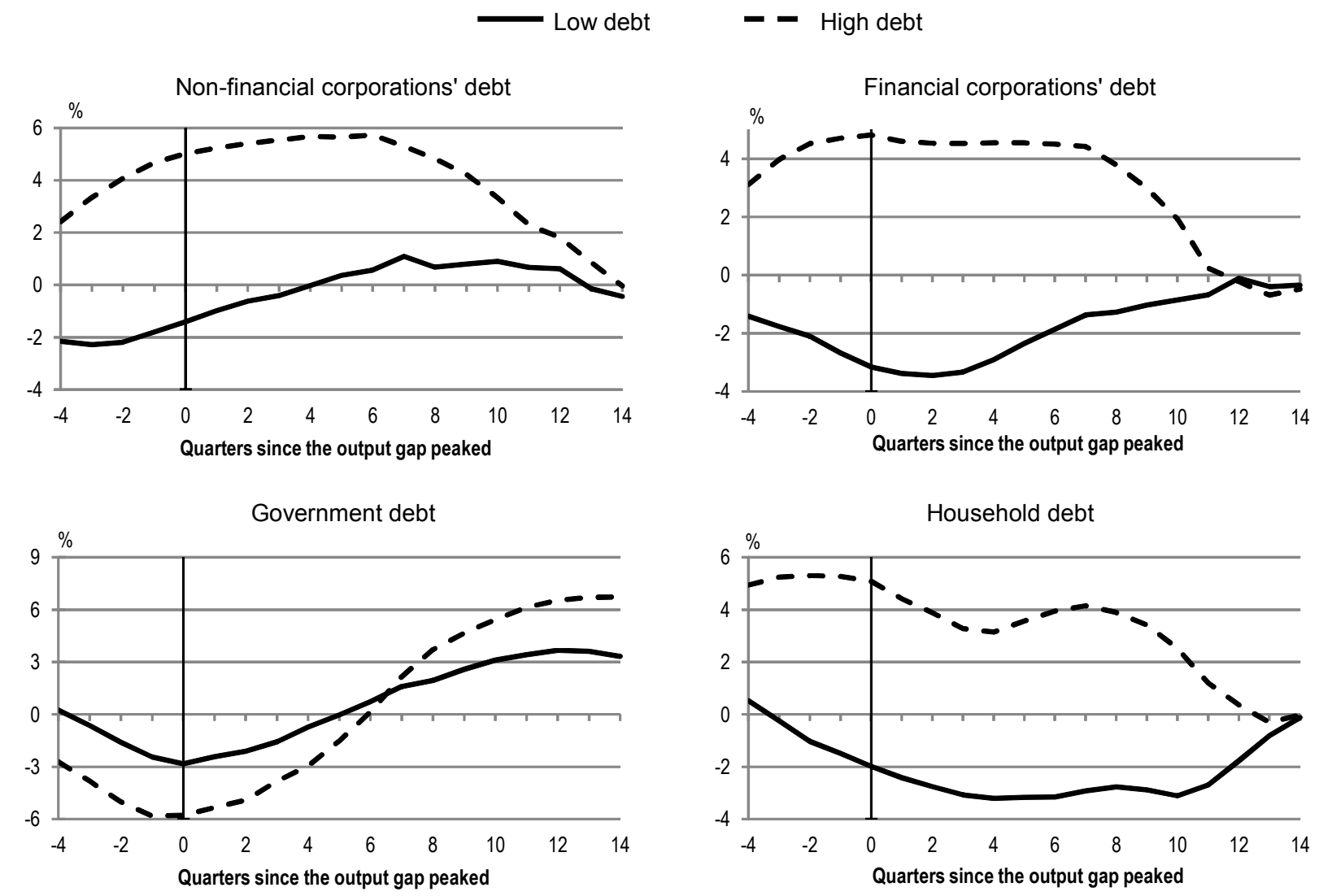

Note: Low and high debt cycles are determined by the level of the "cyclical" component of debt to potential output at the peak of the cycle. The lines correspond to average percentage deviation paths for the corresponding variable relative to the long-term trend.

Source: OECD Economic Outlook No. 91 and OECD National Accounts databases.

The analysis of debt dynamics by institutional sector shows that the assessment of debt levels greatly depends on the indicator. For households for instance, debt is only very high at business cycle peaks if it is measured in terms of disposable income or GDP (Figure 8). On the other hand, since financial and non-financial assets rise even more than financial liabilities over high-debt business cycles, households' net financial wealth and worth is even positive at high-debt peaks which explains why leverage measures such as debt over net financial wealth or debt over net worth do not exhibit significant differences between the two types of business cycles at the onset of the downturn (lower panels in Figure 8). Thereafter, however, household leverage sharply increases during high-debt slowdowns while they remain fairly stable during low-debt slowdowns. 
Figure 8. Household debt indicators by type of business cycle

Low debt

- High debt

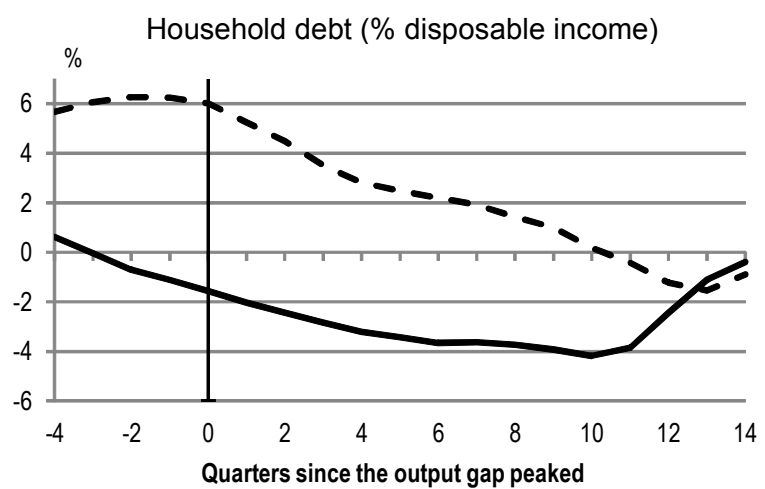

Household net financial wealth (\% of disposable income)

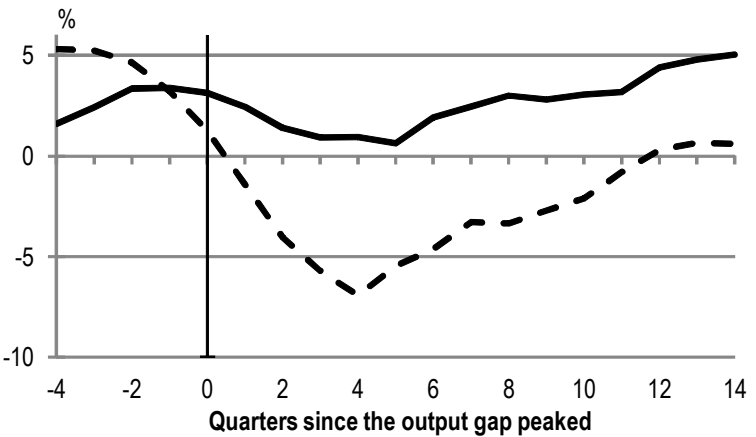

Household debt (\% of financial wealth)

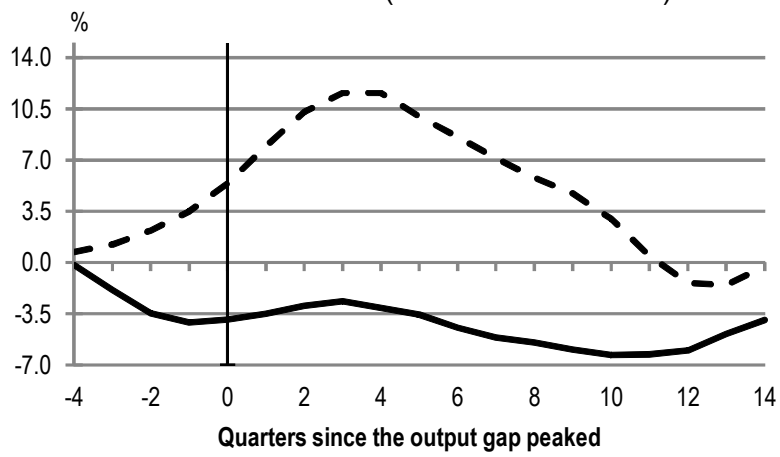

Household debt (\% of net wealth)

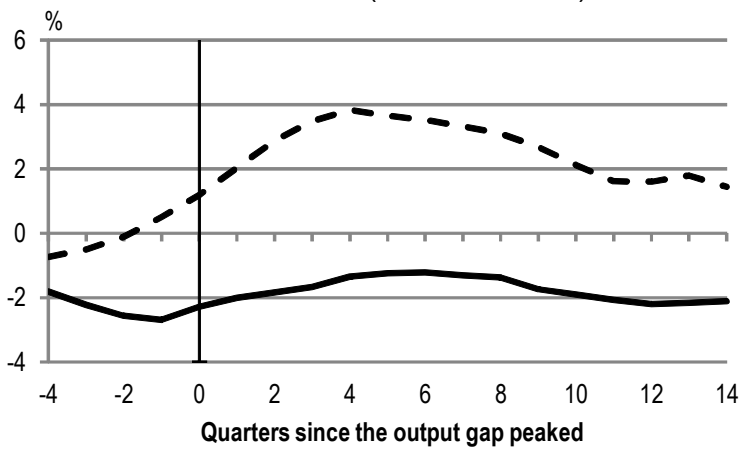

Note: Low and high debt cycles are determined by the level of the "cyclical" component of debt to potential output at the peak of the cycle. The lines correspond to average percentage deviation paths for the corresponding variable relative to the long-term trend.

Source: OECD Economic Outlook No. 91 and OECD National Accounts databases.

This highlights the increased vulnerability of households in situations where both liabilities and assets are high compared to disposable income or GDP. Indeed, asset prices are more volatile and more reactive, especially in downturns, than the value of liabilities. As a consequence, households' financial wealth tends to fall considerably following adverse shocks to asset prices, including house prices. Leverage peaks on average four quarters after the peak of the output gap (lower panels in Figure 9).

Similarly, financial and non-financial corporations' debt is high at high-debt business cycle peaks only when measured with respect to GDP (Figure 7). On the contrary, debt-to-equity and debt-to-asset ratios do not exhibit abnormally high levels at the onset of a downturn (Figure 9) but increase strongly thereafter as assets and equity decrease earlier and faster than debt. 
Figure 9. Corporate leverage by type of business cycle
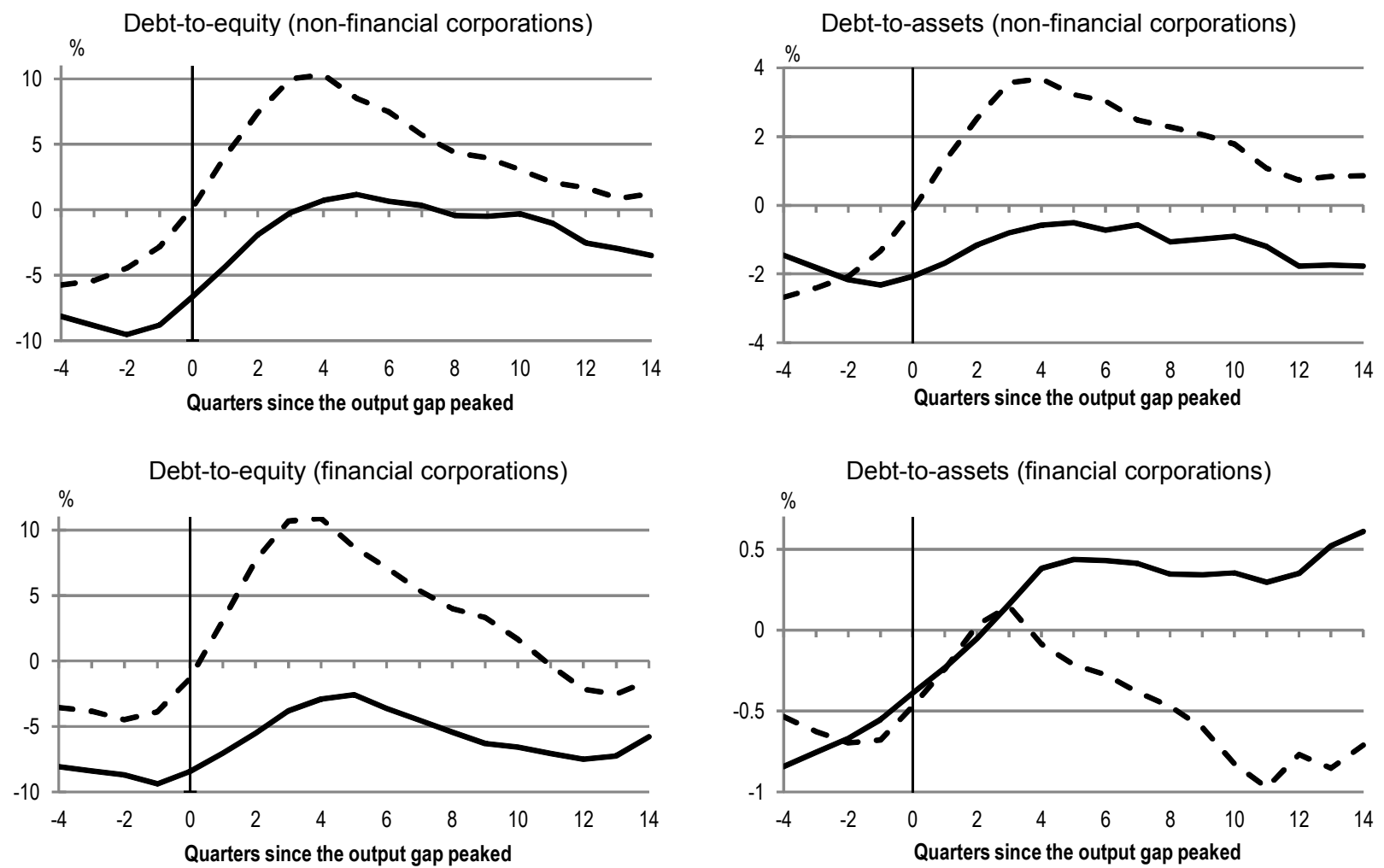

Note: Low and high debt cycles are determined by the level of the "cyclical" component of debt to potential output at the peak of the cycle. The lines correspond to average percentage deviation paths for the corresponding variable relative to the long-term trend.

Source: OECD Economic Outlook No. 91 and OECD National Accounts databases.

\section{The amplitude of business cycles}

\subsection{Real output around high and low-debt peaks}

GDP and its main components exhibit greater output amplitudes in high-debt than in low-debt business cycles (Figure 10). Real GDP exceeds potential output by roughly $4 \%$ at high-debt business cycle peaks but by only $2 \%$ at low-debt business cycles peaks. The peak-to-trough distance for output gaps amounts to approximately $6 \%$ for high-debt episodes while the output gap only declines by around 3\% during low-debt business cycle slowdowns. These patterns are similar for real private consumption and real total investment albeit with higher amplitudes for investment. Deviations from trend are smaller for real government consumption though the pattern of counter-cyclical policy is visible during high-debt slowdowns before readjusting downwards in light of increasing public debt (Figure 7). 
Figure 10. Output deviation from trend by type of business cycle

Low debt $\quad$ - $\quad$ High debt
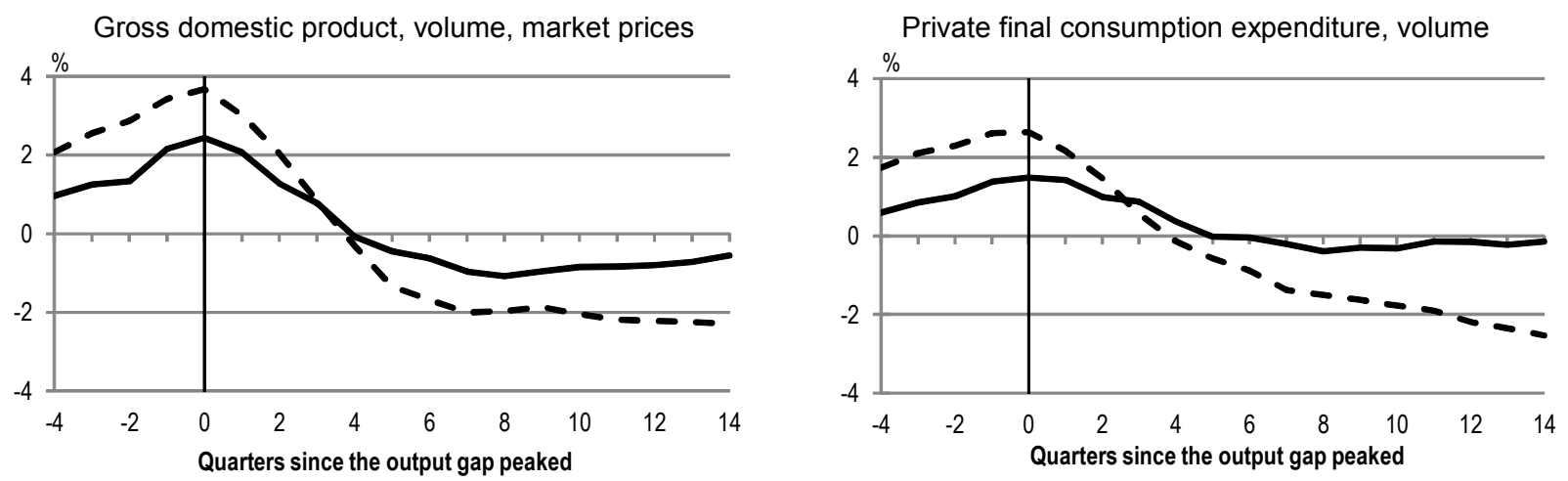

Gross fixed capital formation, total, volume

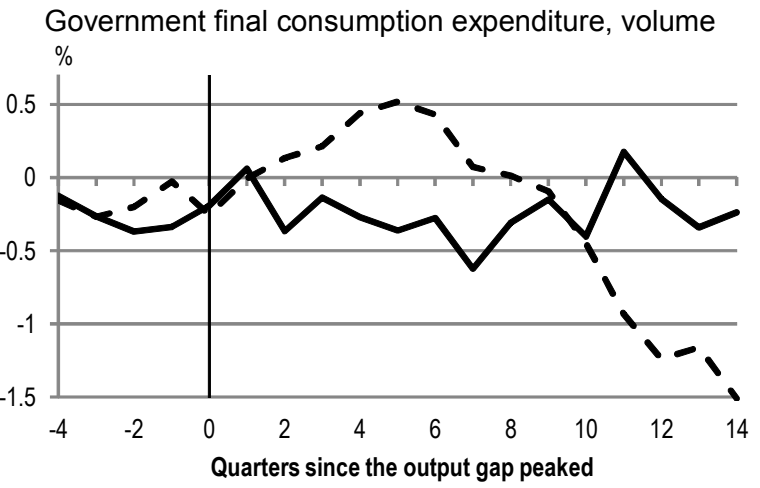

Note: Low and high debt cycles are determined by the level of the "cyclical" component of debt to potential output at the peak of the cycle. The lines correspond to average percentage deviation paths for the corresponding variable relative to the long-term trend.

Source: OECD Economic Outlook No. 91 database.

High and low-debt deviation business cycles also differ in terms of duration. High-debt expansions typically last longer than low-debt expansions and the subsequent slowdown is not only more substantial in terms of the magnitude (Figure 10) but also more rapid after high-debt peaks (Table 2).

Table 2. Deviation cycle amplitudes

\begin{tabular}{lccc|ccc}
\hline & & \multicolumn{4}{c}{ High debt } \\
& $\Delta$ OG $(\%)$ & $\Delta$ Real GDP $(\%)$ & $\Delta \mathrm{t}$ (quarters) & $\Delta$ OG $(\%)$ & $\Delta$ Real GDP $(\%)$ & $\Delta t$ (quarters) \\
\hline Trough-to-peak & 3.4 & 11.0 & 9.7 & 4.3 & 14.0 & 13.6 \\
Peak-to-trough & -3.6 & 5.0 & 8.0 & -5.9 & 3.2 & 6.8 \\
\hline
\end{tabular}

Note: Deviation business cycles are split into low-debt and high-debt cycles according to de-trended debt-to-trend-GDP ratios at the peak of the deviation cycle. OG denotes the output gap.

\subsection{The housing channel}

High-debt episodes are typically accompanied by substantial asset price movements, on the up and on the downside. Especially the amplitude of house prices markedly increases in such episodes with respect to low-debt business cycles (Figure 11). And, there is a link between strong house price increases and housing investment booms. Indeed, volatility of house prices seems to carry over to investment. At output gap peaks, housing investment is approximately twice as much above trend in high-debt deviation cycles as compared to low-debt deviation cycles. The results further suggest that rapid declines in housing 
investment and rapid declines in house prices may lead to destruction of the economy's capital stock (lower-right panel in Figure 11).

Figure 11. Housing investment and capital stock by type of business cycle
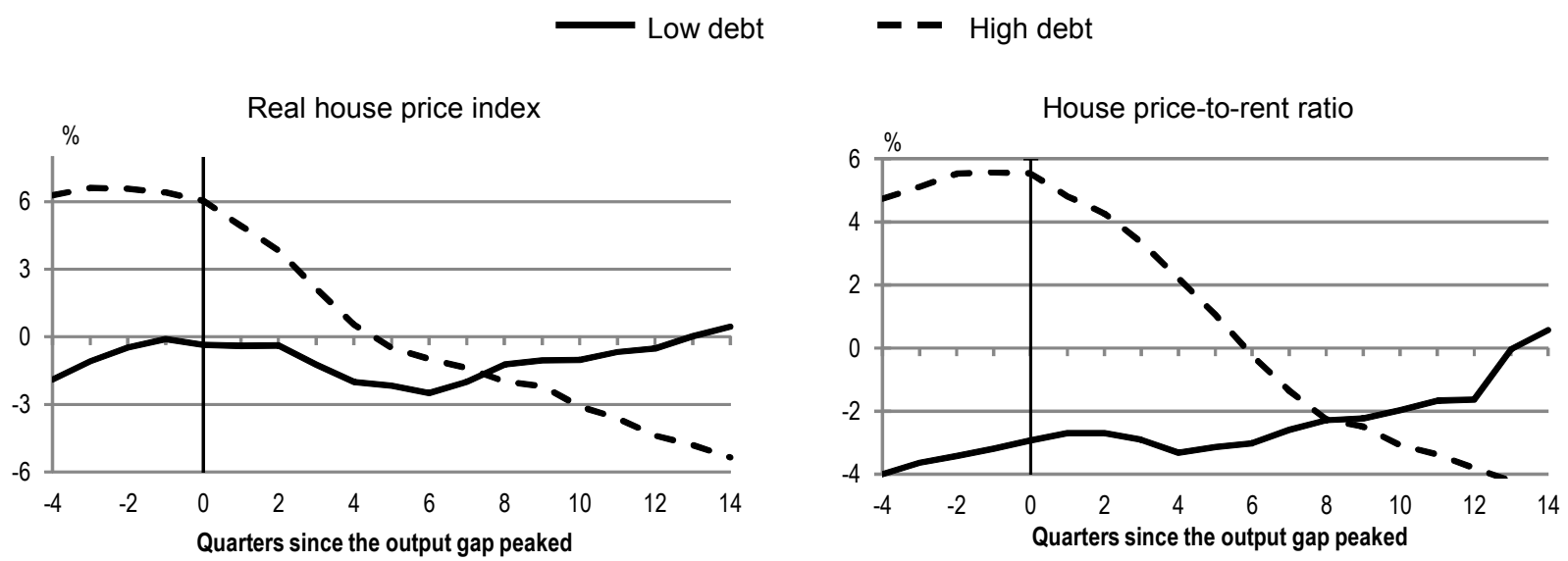

Gross fixed capital formation, housing, volume
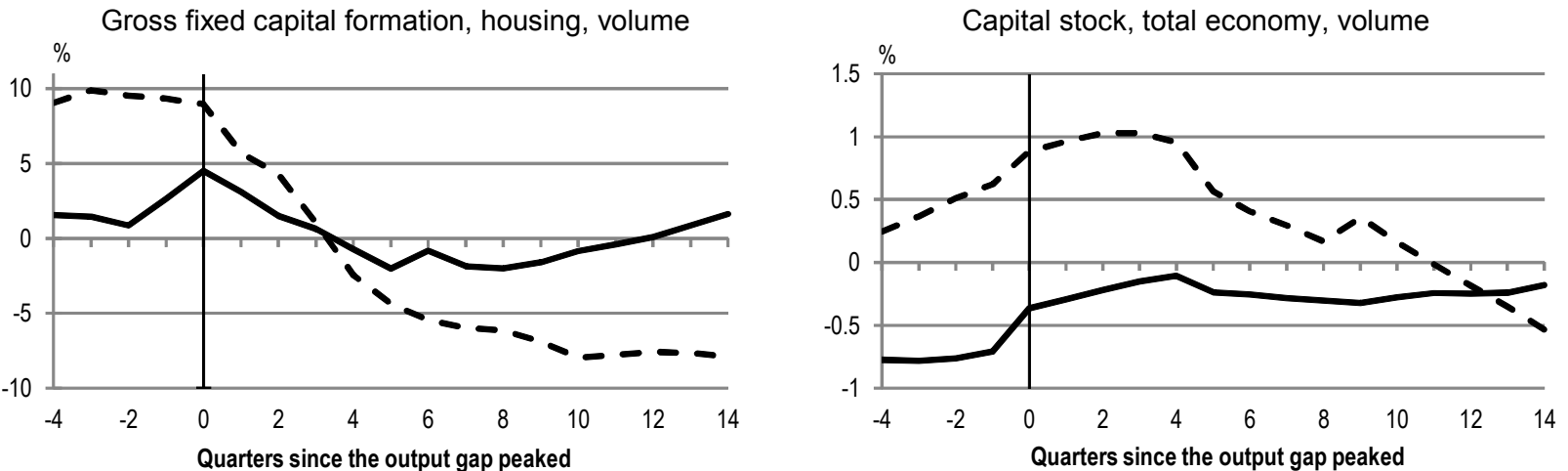

Note: Low and high debt cycles are determined by the level of the "cyclical" component of debt to potential output at the peak of the cycle. The lines correspond to average percentage deviation paths for the corresponding variable relative to the long-term trend.

Source: OECD Economic Outlook No. 91 database.

\subsection{The international channel}

Trade is also substantially more volatile during high-debt slowdowns than during low-debt slowdowns (Figure 12). Interestingly, real exports are at comparable levels at the peak of the business cycle with respect to long-term trends, while real imports exceed the long terms trend markedly in high-debt business cycles which reflects the boom in domestic demand highlighted above (Figures 10 and 11). As a result, business cycles differ: high-debt peaks occur much more frequently in current account deficit countries and current account imbalances are more pronounced around the peak of high-debt business cycles as compared to peaks of low-debt business cycles. 
Figure 12. Exports, imports and the current account balance by type of business cycle

Low debt

Exports of goods and services, volume

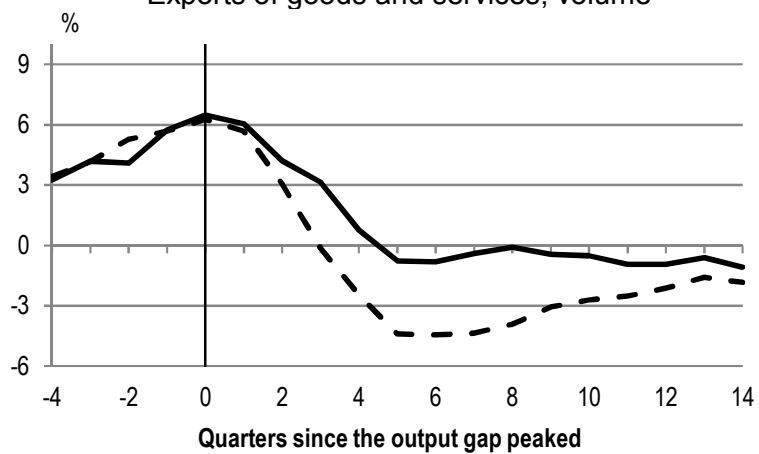

- High debt

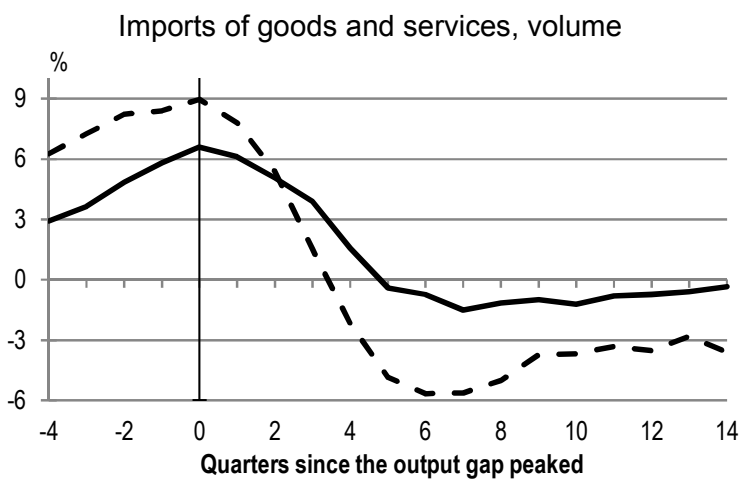

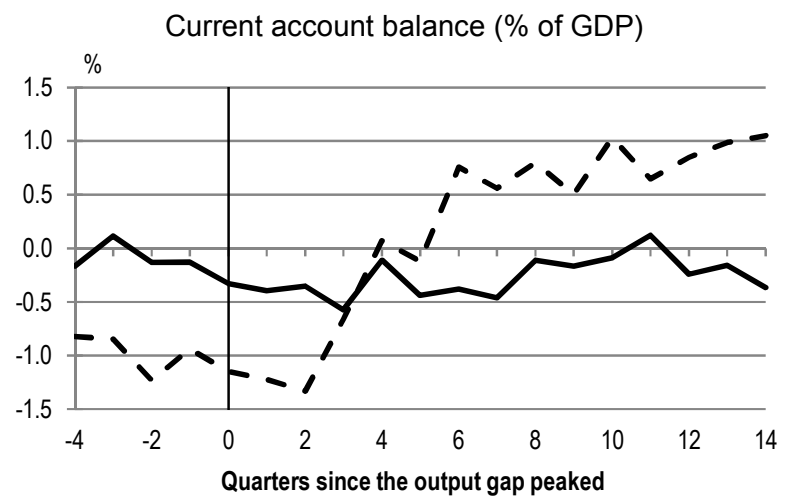

Note: Low and high debt cycles are determined by the level of the "cyclical" component of debt to potential output at the peak of the cycle. The lines correspond to average percentage deviation paths for the corresponding variable relative to the long-term trend.

Source: OECD Economic Outlook No. 91 database.

External debt, particularly short-term debt in foreign currency, exceeds its long-term trend by a wide margin during downturns of high-debt business cycles. Previous findings show that external debt, currency and maturity mismatches may induce financial fragility (Ahrend et al., 2012). The observation of excessive external debt, especially in foreign currency, prior to high-debt troughs is consistent with the finding in this paper that slowdowns following high-debt peaks are more violent and accompanied by substantial decreases in financial asset prices. 
Figure 13. External debt by type of business cycle
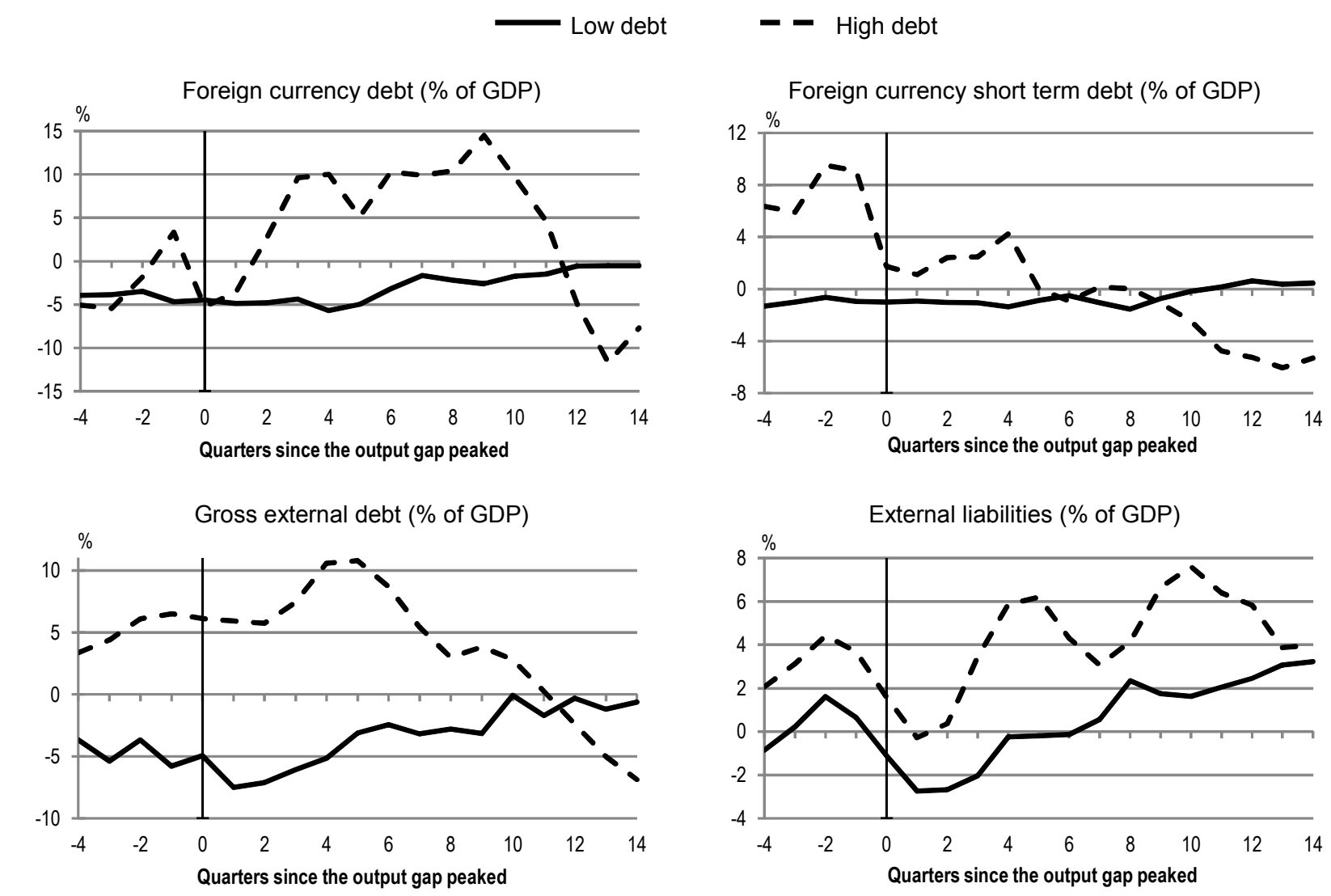

Note: Low and high-debt cycles are determined by the level of the "cyclical" component of debt to potential output at the peak of the cycle. The lines correspond to average percentage deviation paths for the corresponding variable relative to the long-term trend.

Source: Joint BIS-IMF-OECD-World Bank Statistics on External Debt HUB (JEDH), OECD Economic Outlook No. 91 and OECD National Accounts databases.

\section{Preferences beyond volatility}

Standard utility functions imply that representative agents do not only care about average growth and output volatility but also exhibit preferences for higher order moments of the output distribution, notably for skewness and kurtosis. Indeed, Scott and Horvath (1980) show that standard assumptions for utility imply that investors have positive preferences for odd (e.g. mean and skewness) and negative preferences (aversion) towards even moments (volatility and kurtosis). Recently, Barro (2009) has shown that extreme events lead to considerable welfare losses exceeding those induced by volatility alone (see also Epaulard and Pommeret, 2003).

In the present sample, the distribution of output growth during high-debt episodes is more negatively skewed and more leptokurtic than during low-debt episodes (Table 3). Negative skewness means that the concentration of quarters of below-average growth is higher than would be predicted by a normal distribution. Positive (excess) kurtosis suggests that the probability of extreme events is higher than in the case of normal distributions. Consumers and investors dislike both. 
Table 3. Summary statistics for real GDP growth rates by debt regime

\begin{tabular}{lc|c|c|c}
\hline & $\begin{array}{c}\text { Average } \\
\text { growth }\end{array}$ & $\begin{array}{c}\text { Standard } \\
\text { deviation }\end{array}$ & Skewness & Kurtosis \\
\hline Low debt & $3.0 \%$ & $2.1 \%$ & -0.36 & 7.34 \\
High debt & $2.5 \%$ & $2.3 \%$ & -2.21 & 14.58 \\
\hline
\end{tabular}

Note: Deviation business cycles are split into low-debt and high-debt cycles according to de-trended debt-to-trend-GDP ratios at the peak of the deviation cycle.

As can be shown by Taylor expansions of utility functions (e.g. Scott and Horvath, 1980), the standard mean-variance arbitrage is only consistent with utility maximisation if either the utility function is quadratic or the wealth distribution is normal. The results shown above (Table 3) and standard utility functions suggest that both are not realistic. As a result, fourth-order approximations of expected utility, that incorporate mean, volatility, skewness and kurtosis of output growth, represent a better fit than second order approximations that only incorporate mean and volatility. A simple application of the expected utility framework confirms that, as compared to low-debt episodes, high-debt episodes induce expected utility losses that increase with the level of risk aversion (Figure 14).

Figure 14. Differences in expected utility by debt regime

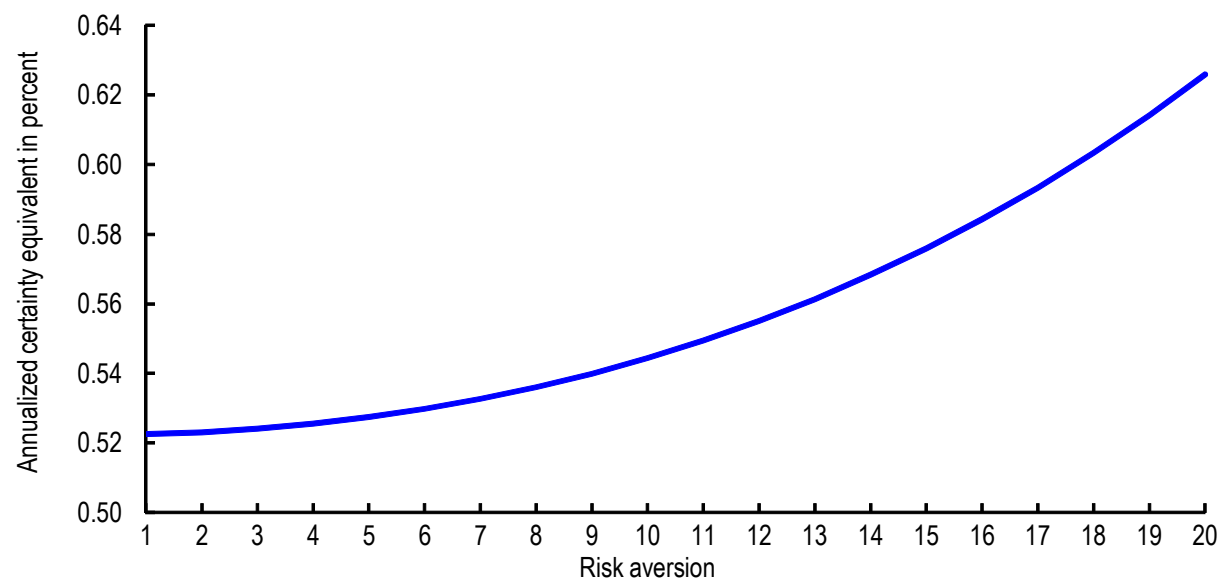

Note: Based on CARA utility, expected utility is estimated as $E(U(\alpha, x))=\frac{1}{T} \sum_{t}-\frac{1}{\alpha} \exp \left(-\alpha\left(1+x_{t}\right)\right)$ where $x_{t}$ denotes the growth rate of real GDP at $t$. The certainty equivalent $\mathrm{CE}$ is the additional growth rate that the representative agent requires in high-debt episodes so as to be indifferent with a low-debt regime: $E\left(U\left(\alpha, x_{H I G H}+C E\right)\right)=E\left(U\left(\alpha, x_{L O W}\right)\right)$.

Consequently, policy making should take the distributional consequences of policy decisions into account instead of merely focussing on expected average growth. Beyond volatility, the probability for the occurrence of extreme events and asymmetric growth outcomes need to be included in policy assessments. 


\section{REFERENCES}

Ahrend, R. A. Goujard and C. Schwellnus (2012), "International Capital Mobility: Which Structural Policies Reduce Financial Fragility?”, OECD Economic Policy Papers, No. 2, OECD Publishing.

Andrews, A., A. Caldera Sánchez and Å. Johansson (2011), "Housing Markets and Structural Policies in OECD Countries", OECD Economics Department Working Papers, No. 836, OECD Publishing.

Barro, R. (2009), "Rare Disasters, Asset Prices, and Welfare Costs", American Economic Review, Vol. 99, No. 1, pp. 243-264.

Basel Committee on Banking Supervision (2010), "Guidance for National Authorities Operating the Counter-cyclical Capital Buffer", Bank for International Settlements (BIS).

Canova, F. (2007), "Methods for Applied Macroeconomics Research”, Princeton University Press.

Epaulard, A. and A. Pommeret (2003), "Recursive Utility, Endogenous Growth, and the Welfare Cost of Volatility", Review of Economic Dynamics, Vol. 6, No. 3, pp. 672-84.

Gourio, F. (2012), "Disaster Risk and Business Cycles", American Economic Review, Vol. 102, No. 6, pp. 2734-66.

Harding, D. And A. Pagan (2002), "Dissecting the Cycle: a Methodological Investigation", Journal of Monetary Economics, Vol. 49, No. 2, pp. 365-381.

Laeven, L. and F. Valencia (2011), "Resolution of Banking Crises: The Good, the Bad, and the Ugly", IMF Working Paper, WP/10/146.

Merola, R. (2012), "Debt and Macroeconomic Stability: Case Studies", OECD Economics Department Working Papers, No. 1004, OECD Publishing.

Schularick, M. and A. Taylor (2012), "Credit Booms Gone Bust: Monetary Policy, Leverage Cycles and Financial Crises, 1870-2008”, American Economic Review, Vol. 102, No. 2, pp. 1029-1061.

Scott, R.C. and P.A. Horvath (1980), "On the Direction of Preference for Moments of Higher Order than the Variance", Journal of Finance, Vol. 35, No. 4, pp. 915-919.

Sutherland, D. et al. (2012), "Debt and Macroeconomic Stability", OECD Economics Department Working Papers, No. 1003, OECD Publishing.

Sutherland, D. and P. Hoeller (2012), "Debt and Macroeconomic Stability: An Overview of the Literature with some Empirics", OECD Economics Department Working Papers, No. 1006, OECD Publishing. 


\begin{abstract}
ANNEX
This annex reproduces some of the main results for growth and classical business cycles in order to check the robustness of the results obtained for deviation cycles in the main text. As far as debt per sector is concerned, deviation cycles (Figure 7) and classical business cycles (left panel in Figure 15) deliver comparable results. Growth cycles (right panel in Figure 15) show slightly different evolutions, mainly due to the fact that the peaks in real GDP growth rates tend to lead peaks in the output gap and peaks of classical business cycles (Figure 4).
\end{abstract}

Figure 15. Debt per sector by debt regime

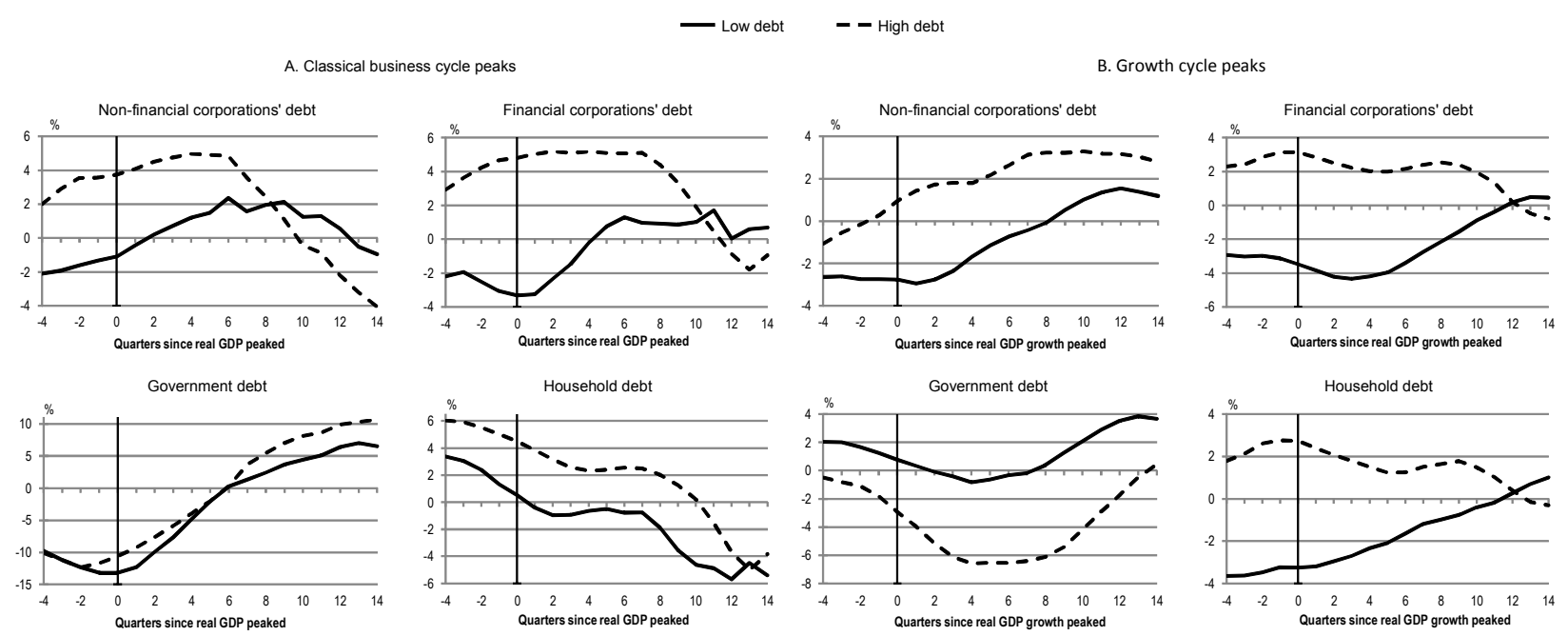

Note: Low and high debt cycles are determined by the level of the "cyclical" component of debt to potential output at the peak of the cycle. The lines correspond to average percentage deviation paths for the corresponding variable relative to the long-term trend.

Source: Financial Balance Sheets of the OECD National Accounts database.

Figure 16 analyses output growth deviations from trend for high and low-debt regimes determined at peaks of classical cycles (left panel) and growth cycles (right panel). Again, the conclusion that high-debt business cycles exhibit greater amplitude than low-debt cycles is confirmed and, again, growth cycles seem to lead classical and deviation cycles (Figure 10). 
Figure 16. Growth by debt regime

A. Classical business cycle peaks

— Low debt

- - High debt

B. Growth cycle peaks

Gross domestic product, volume, market prices
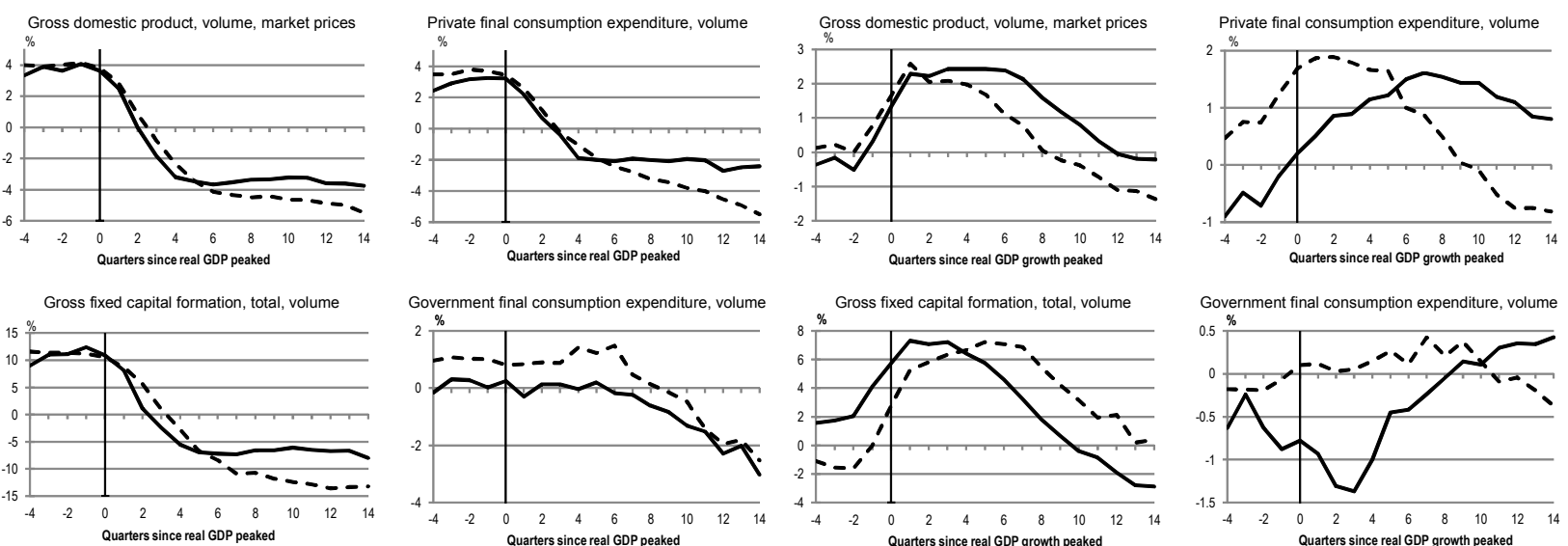

Note: Low and high debt cycles are determined by the level of the "cyclical" component of debt to potential output at the peak of the cycle. The lines correspond to average percentage deviation paths for the corresponding variable relative to the long-term trend. Source: OECD Economic Outlook No. 91 database. 


\section{WORKING PAPERS}

The full series of Economics Department Working Papers can be consulted at www.oecd.org/eco/workingpapers/

1004. Debt and macroeconomic stability: Case studies

(December 2012) by Rossana Merola

1003. Debt and macroeconomic stability

(December 2012) by Douglas Sutherland, Peter Hoeller, Rossana Merola and Volker Ziemann

1002. Reducing greenhouse gas emissions in a cost effective way in Switzerland.

(December 2012) by Anita Wölfl and Patrizio Sicari

1001. Strengthening innovation in the United States

(November 2012) by David Carey, Christopher Hill and Brian Kahin

1000. Long-term growth scenarios

(forthcoming) by Åsa Johansson, Yvan Guillemette, Fabrice Murtin, David Turner,

Giuseppe Nicoletti, Christine de la Maisonneuve, Philip Bagnoli, Guillaume Bousquet and

Francesca Spinelli

999. Selected aspects of household savings in Germany - evidence from micro-data

(November 2012) by Christina Kolerus, Isabell Koske and Felix Hüfner

998. Improving the tax system in Indonesia

(November 2012) by Jens Arnold

997. Unleashing business innovation in Canada

(November 2012) by Alexandra Bibbee

996. Public policy and resource allocation: evidence from firms in OECD countries

(October 2012) by Dan Andrews and Federico Cingano

995. Promoting SME development in Indonesia

(October 2012) by Annabelle Mourougane

994. Portugal: Rebalancing the economy and returning to growth through job creation and better capital allocation.

(October 2012) by Álvaro Pina and Ildeberta Abreu

993. Public debt, economic growth and nonlinear effects: Myth or reality?

(October 2012) by Balázs Égert

992. Choosing the pace of fiscal consolidation

(September 2012) by Lukasz Rawdanowicz

991. Tertiary education developing skills for innovation and long-term growth in Canada (September 2012) by Calista Cheung, Yvan Guillemette and Shahrzad Mobasher-Fard 
990. $\quad$ Trade and product market policies in upstream sectors and productivity in downstream sectors: firm-level evidence from China

(September 2012) by Maria Bas and Orsetta Causa

989. Intangible assets, resource allocation and growth: a framework for analysis

(September 2012) by Dan Andrews and Alain de Serres

988. Current account benchmarks for Turkey

(September 2012) by Oliver Röhn

987. Structural reforms to boost Turkey's long-term growth

(September 2012) by Rauf Gönenç, Oliver Röhn, Vincent Koen and Şeref Saygili

986. Tackling Turkey's external and domestic macroeconomic imbalances

(September 2012) by Oliver Röhn, Rauf Gönenç, Vincent Koen and Ramazan Karaşahin

985. Portugal: Solid foundations for a sustainable fiscal consolidation

(September 2012) by David Haugh and Stéphane Sorbe

984. Portugal: Assessing the risks around the speed of fiscal consolidation in an uncertain environment

(September 2012) by Stéphane Sorbe

983. The German labour market: preparing for the future

(September 2012) by Felix Hüfner and Caroline Klein

982. Climate change policies in Germany: make ambition pay

(September 2012) by Caroline Klein

981. Restarting the growth engine in Finland

(September 2012) by Henrik Braconier

980. Import Competition, Domestic Regulation and Firm-Level Productivity Growth in the OECD (September 2012) by Sarra Ben Yahmed and Sean Dougherty

979. Non-Parametric Stochastic Simulations to Investigate Uncertainty around the OECD Indicator Model Forecasts

(August 2012) by Elena Rusticelli

978. $\quad$ Measuring GDP Forecast Uncertainty using Quantile Regressions

(July 2012) by Thomas Laurent and Tomasz Kozluk

977. Implications of output gap uncertainty in times of crisis

(July 2012) by Romain Bouis, Boris Cournède and Ane Kathrine Christensen

976. Avoiding debt traps: financial backstops and structural reforms

(July 2012) by Pier Carlo Padoan, Urban Sila and Paul van den Noord

975. Sluggish productivity growth in Denmark: the usual suspects?

(July 2012) by Müge Adalet McGowan and Stéphanie Jamet 